\section{Briginal surticleg.}

\section{TYPHOID SPINE. ${ }^{1}$}

\author{
uY R. W. LOVE'T, M.L., \\ Surgeon to the Boston City Hospital, \\ ANI) \\ chas. H. WI'TIIN(dTON, M.D. \\ Physician to the Boston City Iospital.
}

Trw name "typhoid spine" was given by (iibney to a condition at times following enteric fever, which was characterized by great pain and sensitiveness of part of the verteloral column, simulating rather closely l'ott's disease. (iibney described four eases and subsequently a fifth, but only the first three cin be aceepted as authentic instances of this condition. (Xibney believed it to be due to a perispondylitis, meaning an acute inflammation of the periosteum and the fibrous structures which hold the spine together. Osler analyzed (iibney's paper, and reported three cases of his own uncler the title, "On the Nenrosis Following Enteric Fever. Known as the 'Typhoid spine." IIe was rather inclined to regard the condition as a neuJosis, in some eases at least, on the grommd that prolonged periostitis lasting for weeks and month and not coming to suppuration was mulikely. He may be quoted as follows: "While, of course, it would be very illogical to assume that all of the instances are due to the same? cause, yet I camnot help feeling that many of them are examples simply of the painful neurosis formerly known as spinal irritation." The three cases observed by him he was inclined to regard as neurotic in character. Quincke reported two cases, like the others in every respect, under the name of "spondylitis typhosa." As to its mature he was inclined to believe that Osler was partly right, although he thought that (aibney's view might have a correct basis. Another case was reported by liönitzer, where a blacksmith, twenty-five years old, four or five months after the beginning of a severe typhoid, was seized with very severe pain in the back, which kept him in the hospital some two months. The ease: presented nervous phenomena, but no unusual symptoms, and followed the general type of the cases of (quincke and Gibney.

These apparently are all the contributions of literature on the subject. 'The nine casess (three of (aib)ney, three of ()sler, two of Quincke and one of Könitzer) reported are all much alike and present the following chancteristics, so far as one can generalize from so few cases. The patients affected are young adults (males in all reported cases). The spinial affection occurs late in the convalescence, or alter it is apparently culed, often alter the patient has returned to work. It may follow an accilent or may occur spontaneously. It affects the lower dorsal or lumbar region. It is attended by curious nervous symptoms, such as paresthesia, variation in surface reflexes, etc. Pain is excessive and rigillity of the spinal column is due more to voluntary inuscular contraction, holding the spine steady, than to the involuntatry muscular spasm, as in tuberculous spondylitis. No system of treatment has been formulated. The prognosis is favorable.

The case to be reported is of interest in comnection 'Read at the meeting of the Buston Sooiety for Medical Inprove-
ment, Decenber 1, 1899 . with previously reported cases for the following reasons: Deformity resulted, which must have been due to a destructive osteomychitis; nervous phenomona of two kinds were present: first, certain sigmata of hysteria; second, phenomena of another kind, showing pressure. 'Taken altogether, it would seem that in this case, at least, the lesion was a mild, self-limited osteomyelitis of the borlies of the vertebrar, which for some reason is attended with nervous symptoms of a character simulating hysteria, yet having some batsis in pressure phenomena.

The patient is a plysician, aged thirty-five years; tall, mather spatre, with good muscular development, and at one time a teacher of physical training. It belongs to a family of rather exeeptional longevity' and vigor, and is one of ten ehildren, all of whom, with the exception of three who died in infancy, are, with the parents, living and well. ()ne annt on the father's side died of epithelioma of the lieatst, and another of sareoma of the humerus. An alunt on the maternal side died at twenty-five of pulmonary tuberculosis, this being the only instance of that disease in the family. 'The patient has hat no illuesses except pnemonia in 1886 and dysentery in 1891. IIe had never had any trouble with his barek. Hle was assistant surgeon of United States Volunteers during the Spanish IVar and served in the Cuban campaign. In camul before Santiago he was taken sick fuly 17, 1898, and had a continuous highl temperature with watery diarrhea for two weeks, and an intermittent temperature for two weeks more, during which the bowels were more regular. The diagnosis of the division hospital was tropical malaria. (On $A$ ugust 14th he left Sintiago for Montauk, being at the time very weak, hut free from fever. $\Lambda$ fter remaining there in the same condition for five days, he came to his home in Central Massachusetts, arriving there on August 2(ith. 'The next day he had a sharp chill, but it was not repeated and he began rapidly to gain strength.

About the 25th of September lie began to notice lameness in the lumbar region, and october tith, after getting very tired, had severe cramps in the same region, which required a hypodermic injection of morphia. He remained in bed for three days, then rapidly improved and began medical practice. He continued to feel perfectly well till November 2(ith, when he had a slight ehill. 'That day he came: to Boston. The next day the cramps in the back returned and grew rapidly worse. IIe remained in bed at a hotel till December 3il, when he entered the City Hospital.

'The physical examination at his entrance was for the most part negative. 'Tlough there had been occasional chills, the temperature was normal. 'The abdomen was tense, tympanitic and slightly tender; no rose spots. $\Lambda$ search for plasmodia was made on December $3 d$, and agrain on December 13th and 30 th, but with negitive results. He complained chietly of severe pain in the lumbitr region, eoming on in spasms of great intensity. These were much agrgravated by gretting out of bed, which, as he was unable to use the bed-pan, he had to do daily. These dorsal pains were very excrueiating and several times required the use of morphia. 'The eflect of massage was to angravate the pain, partly because the treatment involved his turning upon his side, which was likely to start up the cramps. Faradism 
also proved useless or injurious, and day after day the pain continued to be distressing, with some loss of sleep. Blood examination soon after entrance showed 7,450 whites, and on December 30th a characteristic typhoid serum reaction was present, clumping occurring in two minutes. Throughout the month of January the pain was still complained of ; at times, especially toward the end of the month, the patient thought it was less intense when at rest, but all attempts to sit up in bed or move at all eaused great distress.

Examination, January 30th, showed on the outer surface of both thighs, extending from trochanter to knee, an area of diminished sensation to pain and touch, most marked on the right leg. Patellar reflexes lively; plantar and abdominal, normal ; cremasteric, sluggish. 'The spines of the lower dorsal and the upper lumbar vertebra were tender to pressure. The museles of the loin were rigid. Three or four days later there was noted a tenderness over the posterior part of the ilium. No swelling to be seen. Considerable muscular spasm. No prominence of any vertebral spines at this time. On being made to stand, patient camnot hold himself erect, and after standing a minute the pain in the back becomes worse. On sitting in an armchair he rests his weight as far as possille: on the ellows. Cannot bear to sit up without such support. After an hour in this position the pain becomes severe but passes off when he goes back to ber. IIe contrives to sit up altogether alont two hours per diay. No rectal or vesical symptoms. Eats and sleeps well.

Felmuary 5th. Paticnt walks about a little with a canc, but moves with great slowness and caution. Rises with much difficulty from the chair, and gets his balance slowly and carefully. In the course of the next four days he could walk the length of the corridor with two crutches, showing some gain in the ability to use the lower extremities. Alout this time a distinct projection of the spines corresponding to the eleventh and twelfth dorsal and first lumbar vertebras was for the first time noticed. There was also noted in consideralule tenderness over the transverse processes of the second lumbar vertebra, worse on the left side. Meantime the patient continued to walk slowly and stiflly with crutches daily. IIe felt more comfortalls, when standing or lying than when in a chair. $\quad \Lambda$ feer a day or two he himself discovered the "knuckle" and was nuch alarmed thereat.

'The patient was first seen by Dr. Lovett in consultation with Dr. Withington Felnuary 11, 1899. $\Lambda t$ that time he was in bed most of the time and was able to go ahout with crutches. There was a wellmarked prominence of the spinous processes in the lower dorsal and npper lumbar region, involving apparently two or threo vertebra; the spine was almost absolutely rigid in passive and active movements; getting from the berl into the erect position was accompanied by intense spasm of the spinal muscles and very severe pain, more so than in Pott's disease, even of a severe type; the knee-jerks were moderately increased and imotion in the legs was apparently good. A provisional diagnosis of "typhoid spine" was made. $\Lambda$ s movement was evidently attended by great irritation and pain, it was decided to put on a plaster jacket, which was applied on February 17 th, with the patient lying proue in a hammock. Less relief followed than is customary after the application of the jacket to pa- tients with Pott's disease, although the patient was somewhat better.

$\Lambda$ s the patient was evidently lospitalized, he left the hospital on February 24 th and went to a hotel. At this time, although movement wats attended with less pain than without the jacket, lie was still very uncomfortable and the erect position was painfui. II walked fairly well with crutches.

The temperature chart, which was carefully kejt during his hospital residence, showed for the first two weeks a sliglit irregularity with elevations not exeeeling $99.6^{\circ}$. About December 17 th a more matred fehrile movement began, aceompanied by slight ehills on four occasions, December $22 d, 283$, , zoth and .lanuary 4th. As already remarked, repeated examination failed to reveal the plasmodia. The fever during the twenty-five days following 1)ecember 17 th ramged mostly from $100^{\circ}$ to $102^{\circ}$, only three times exceeding the latter figure. $\Lambda$ fter bannary 10 th the curve returned to about the sime character as during the first two weeks, only once reaching as high as $100^{\circ}$, but showing a constant diurnal valiation from about $98^{\circ}$ in the mornings to $983^{\circ}$ or $999^{\circ}$ in the evenings. After he left the hospital the evening temperature, which was taken at intervals, was always found to be normal.

On March 1st the plaster jacket was opened, a strip cut away to allow it to be brought tighter and it was fastened with straps, but with this ho was less comfortable than with the fixed jacket, and on March 8th a second jacket was put on, again in the hammock position. 'This jacket was purposely put on very tight and each turn of the bandage pulled with all reasonable force. Inmprovement in the pain immediately followed and he was able to be about more, although alles to do very little. $\Lambda$ s soon as lie began to be freer from pain it was noticed that the power in lis legs was poor and that he was evidently suffering from some muscular impairment of motion. Ilis knee-jerks were decidedly increassed and he hat some ankle clonus. $\Lambda$ t this time another test of the blood gave a positive Widal reaction.

On March 10th he was seen hy Mr. Withington in consultation with Dr. Lovett. Ile was found to be walking with erutehes a little better than when he left the hospital, but the getting out of bed and assuming an erect attitude was attended with great, difliculty, apparently not so much from pain as from loss of power. When lying recombent he raised the legs from the bed with great difliculty, the paresis in each being equal. Muscular senses was good. Tactile sensation good, except in the areas on ontside of the thighs before noted. No impaiment of sphincters. No atrophy. Patellar reflex increased, slight ankle clonus. No rigirlity or contractions of legs. $\Lambda_{p p e-}$ tite and other bodily functions good. Patient cheerful and hopeful.

On March 11 th he was seen by Dr. Mortom Prince in consultation with Dr. Lovett. Examination showed very much increased knee-jerks, slight ankle clonus, two anesthetic patches, one on the outside of each thigh, and impaired muscular power in the movements of the legs. In addition to this there wats a greater clisability in getting alout, rising from a chair, etc., than seemed to be explained hy the impairment of muscular power. According to Dr. Prince the signs found were confusing, somewhat contraulictory, and not claracteristic of any type of spinal lesion; at the 
same time the anesthetic patches were constant and definite, and Dr. P'lince folt that there had been compression present, which accounted for part of the symptoms, but that the present condition as a whole, ajurt from this, was rather to be classed as hysterical. The patient in other respects although, not a hysterical man, showed the effect of long confinement in bed and severe pain in mental excitability and dread of pain. Dr. Princes's diagnosis was, therefore, some form of comperession, with hysterical symptoms. $\Lambda \mathrm{t}$ his adviee massage: to he legs was given daily and the patient improved rapollly.

'The third jacket was put on $\Lambda_{\text {pril }}$ lst, and at that time photegraphes of the: bacek were taken showing de:formity. $\Lambda$ t this time another examination of the blood showed a positive Widal reaction. The patient left for Virginia on $\Lambda_{\text {pril }}$ (ith. On April 11 th, 13th and 15th he hat ehills and high temperature, probably of malarial origin. At the time that he left for the South he was able to walk with erutehes or for a short listance with cannes.

In .July, 1899, he reported to Dr. Lovett, still wearing his jacket. For a month previous to this he had been able to walk a mile or two without assistance, he could platy golf, and was unconscious of any pain whatever in his back so long as the cast was applied. 'The cast was cut and fastened with straps, and on the sueceeding day, as the cast was soft and afforded improper support, he began to feel fitigue and discomfort in his back again. $\Lambda_{11}$ accuratedy fitted leather jacket, re-enforeed with steel, was then made, which immediately relieved his symptoms, and the patient returnerl south anain.

()in ()etober 3 k, he reported, still wearing the lenther jacket. $\Lambda$ t this time he was able to ride horschatek, walk long distances, hunt, and hat gained aloout thirty pounds in flesh. 'The doformity was still present, alihongh less evident on account of the better development of the muscles. 'The movement of the spines was perhaljs two-thirels of the normal in all directions. Whon standing with the knees straight le: could stoop so that the liancls eime within sixteen inches of the floor, he had no pain in movements and very slight temlerness in the spine; what there was reminined ehiefly over the trinsverse processes of the second lumbar vertelin. $\Lambda$ this time he returned to the practice of meslicine, the only restriction being that he should lie down for an hour and a half in the mirldle of the day.

(1) November 16, 1899, he reported again. 110 was engagerl in the active practice of medicine and was able to do his full work without discomfort or fatigue. 'The movements of the spine had improved, and he conld go without his jacket two or three hours without discomfort, and with the knees slyaght he conlel stoop) to within thirteen inches of the floor. Teuclemess of the back hat disappeared, but the anesthetie patches on the outsicle of the thigh persisted to a slight extent.

(11 Jecember 2, 1899, he reported that he was getting alone very comfortably, was able to do his full still werl that he hat no discomfort in his back, was still wearing lis leather jacket and spent one hour and a half a day in the recumbent position. The first questions which arise are whether the pa-
tient had typhoid fever, and if so when? 'To the former we cail at once reply aflirmatively, on the strength of the unusually prompt and positive response to the
Widal test on December 30 h, which seems to be the first date at which the test was applied. 'This was confirmed by subseyuent tests. 'That he had never had typhoid prior to his Cuban experience we call be sure. Did, then, his typhoid oceur in ('uba or soon after his residence at Montauk (where typhoid pre:vailed), or was it first present cluring the felbile movement which occurred in the hospitill? None of the signs of the discase, in the way of roseola, spleen or diarrhea were noted while he was in the hosprital, and it is more reasomalole to suppose that his attack in Cuba was, like that of many other soldiers, a mixed infection by malaria and typhoid. 'Jhe fixing of the disease in July would also be more consistent with the first occurrence of the spinal symptoms in ()etober, and the fever curve of December and .January, if not typhoid and not malaria, is quite explainable by the spondylitis, as will be seen loy comparison with other cases montioned hereafter.

With regard to the exclusion of tuberculous distase of the spine it may be saicl that the elinieal aspect of the case was not that of ordinaly Pott's discase. 'The muscular rigidity seemed largely voluntary, the pain was excessive, tenderness of the spine was present and there was pain referred to the peripheral ends of the nerves. 'The tuberculin test was negative. The Widal test, was positive. 'The subsequent history of the case and the rapid recovery, good molility of the spine returning within nine months of the most acute period, is not characteristic of severe l'ott's diseatse in the anlult.

'The so-called typhoid spine means, aceording to different authors, either (1) a neurosis or (2) is spondylitis or perispondylitis. 'The former view is helel by (Osler, the latter by (iibuey, and in part by (Quincke. In our case some of the symptoms would correspond to a neurosis, as, for example, the distrilution of the areas of anesthesia on the thighs, the increased reflexes, ankle clomus, etc. But the character of the projection of the spinous processes of the vertehra mate it evident that in this case there must be present a destructive inflammation of the vertebral bodies in the lower dorsal regrion. As may be seen in the pieture, the projection was of consilerable size, the spinous processes could be easily made ont and their angular projection could only be aceounted for by the giving way of some part of the weight-bearing portion of tho vertebral column. A periostitis conld not explain it; one must assume an osteomyelitis to have been present. So far as the writer's lave been able to learn, this is the only ense of well-anthenticated typhoid spine accompanied by deformity.

'The cases of Quincke are of special interest in this connection. In the first case the fever was over on the fifieenth day. On the twenty-lirst day occurred a relapse, which lasted a week. ()n the thirty-iourth day occurred a rise of temperature and lumbar pritr. 'There was pain on rising in bed and tenderness over both sicles of the spinal processese. 'This lasteel but a few days and the pationt sat up at the end of seven weeks. In a day or two the symptoms returned with greater violence and lasted altogether from two to three mouths. 'There was chill, irregular feverr, swelling in the right lumbrr regrion, girdle sense, retention of urine, and for a short time diminution of the patellar reftex. In the second case the typhoid was milder but more protracted. 'Towards the end of the fever there was a transient periostitis of the parietal 
bone. The vertebral disease showed itself ten weeks after the defervescence, and several weeks after the resumption of work (blacksmithing). During the period of the spondylitis there was fever of an intermittent type. In botli eases the lumbar spine was chiefly involved, but covering a large area, namely, four to six vertelore. In both there was visible swelling of the soft parts and tenderness of the vertebral spines and bodies. Both cases showed paresthesia of the lower extremities and slight rigidity in some of the leg muscles. 'The dimitation of movements was due chiefly to the pain, but it was not certain that there was any true paresis. (Quincke conclucles from analogy of the visible changes in superficial bones that there was in these cases an inflammatory swelling of the periosteum, with scrous infiltration on the inner as well ats the outer surfice of the vertehral column which eompressed the nerve roots of the cauda equina in the second case, while in the first case (in which the process involved the lower dorsal vertehras), there: was also compression of the inferior part of the conus medullaris, which would aceome for the bladder and rectal paresis in that patient.

Numerous observers have now demonstrated the occurrences of the typhoid hacillus in hone marrow, and this organism has come to be recognized as one of the many morlbific agents concerned in bone inflammation. In those cases of "typhoid spine," therefore, in which spondylitis lats a part, the latter may be: considered as one phase of the bone involvement of typhoid, which in the case of the tibia, the ribs and the fomur we have learmed to expect. It is, therefore, interesting to recall that in one of ( quincke's cases there lad been carlier in the typhoirl a periostitis of the parietal bone, which had undergone resolution. If we are, to assume, in addition to the massing of typhoid bacilli in the vertehra, some local strain or injury involving those parts, it is likely that laborious work, undertaken before the bodily strength is fully reestablishexl, may serve as such a factor. In one of Quincke's cases such a strain might have come from the ocenpation of the pationt, who walked and climbed stairs carrying a peallier's pack, and in the other from his trade as a blacksmith, in which he haul resmmed swinging a heavy hammer for some time before the oulset of the spinal symptoms. 'The same is true of Könit\%er's patient, also a blacksmitlı. In our patient the active practices of medicine had perhapss been taken up too soon. In (iibney's first case the pain in the baek hegan during convalescence; in the second case after a railond journey undertaken during convalescence; in the third case spinal symptoms began after a fall in skating after convalescence seemed cuded. In these cases there is no mention made of any unusual nervous condition.

Is the so-ralled typhoid spine a neurosis or a bone lesion?' 'Two of the prominent authors who have recently answered this question have given their replies in accordance with theis respective points of view, ()sler, from the medical side, considering it a neurasthenic; phenomenon, and (xibney, from the surgical, a perispondylitis. (Osler's minor cases ${ }^{2}$ especinlly suggest nouroses, in the brevity of their course and their onset at aloont the hegrinning of typhoid convalescence. His first group of cases, ${ }^{8}$ however, are more similia. clinically to Gibncy's, coming on from three to cight

2 Johns Hopkins Hospltal Reporte, vol. v, p. 316.

Ibid, vol. Iv, p. 73 . weeks after convalescence, and lasting each for several months. Ifo also includes a case in which there was diminished sensation in the legs with paresthesia, but no pain or tenderness of the spine, occurring in an alcoholic and venereal subject, after typhoid.

The longevity of the typhoid bacillus in eertain parts of the body is woll known, as for example, in the gall-bladder and in bone marrow of some of the typhoill bone lesions.

D1. l'arsons ${ }^{4}$ emplasigen this latemess in the evolution of typhoid ostitis and periostitis, saying that they vary from one to sixteen months after the fever. With one exception they have never been known to

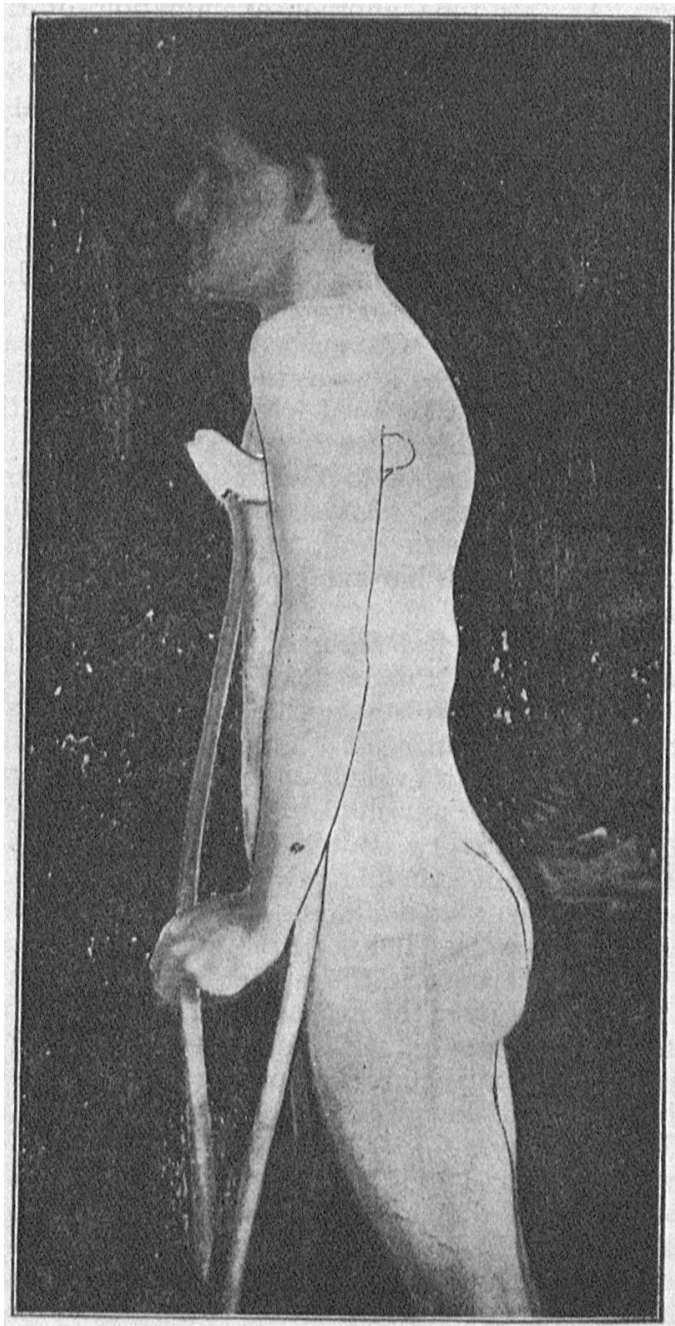

occur during the course of the fever. Necrosis and suppuration do not always take place. Parsons thinks that such casess as Gibney's perispondylitis are perlayps to be considered as belongring to the same? category with the more common typhoid lesions in the tibia, and other long bones, the sternum, atc., though the bacteriological proof is wanting.

The case upon which this paper is based had been considerexl, up to the time of the development of the knuekle, to be a post-typhoid neurosis. IJad the deformity not appeared it would probably have continued to be so regarded. Reasoning from the analogy of

- Jolıns Hopkins Hospital Reports, vol. v, p.417. 
othey pest-lyphoidal bone lesions, we may conclude mothorax before, I laul no donbt of the diagnosis here. that an osteompelitis or possibly periostitis of the The dominant symptoms being pain alld dyspmeat on vertelorat is present. in some of the cases which have motion, he was given small doses of morphine and been supposed to bolong in the neurotic: elass of antifebrin and kept in bed, with mild comnterirritants lyphoid spines.

\section{BIBI.IOGKAPHY.}

Gibney. Transiactions American Orthopedic Association, vols. ii ind iv.

Osler. Johns Hopkins Hospital Reports, vols. iv and v.

Quincke. Mitthoil. aus den (ìronzyeb. der Medicin and Chir. $18 ! 18$, p. 585

Könitzer. Muinch. med. Woch., August 2!), 1899, p. 1145.

Parsons. Joluns Hopkins Hospital Reports, vol. v.

Keen. 'The Surgieal Complications of Typhoid Fover.

\section{IDIOPA'THIC PNEUMOHEMATO'TIIORAX, WITII RECOVERY AFTliR ASPIRATION.'}

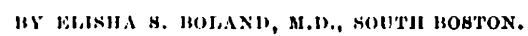

Mr. 'T'. is thirty-four years of age, married. Born in Maine. Nover serionsly sick, except some eight years ano, when he: was conitined to the house two on ihree weeks with the "errjp." Doring early matrlood he followed the sea, and at this work gained the stummit of his weight, 170 pounds; present. woight about 1 is) pounds. Situr he gave up going to seat he worked as a matble: enter for some time, but gave this Iy hy the arlvice of his physician, as there was some premonition of long trouble. Of late yeats: he has been at work in a proceny and provision store, meat cutting, ete. Sometimes has felt pain in right side when he had to shoulder or carry a heavy quarter of beef. Ile is ereet, spare, active and stronge, of temperpate laabits, and takes good cares of limself. Family history is megative as to phthisis. Father alive and well at sixty-four; mothor died at thirt,y-live: ahtse of mother's death not known. Ile was in his nsunl health and did his work on July 20, 18!)!. 'That evening, while sitting near an open window - it being very walm - he felt some pain ahout the waist on the right sides $\Lambda$ fter this he remember's he got ne, stretehed himself vigorously and went to bed, whele he slept a fow hours. When, during the night, loc awoke lae felt very severe pain in the right chest in front, and had "a foeline of wind escapling there," and found motion of any kind made it worse, and felt weak and was feverish and short of breath, and suffered much until moruing.

When I found him at 8.30, July 21 st, he was lying on his left side, and could not net sit w) or turn witliont great pain and lyspmea. Pulse 108 , temperature $102^{\circ}$, respirition 28 and shallow. 'There was a pale, cythotic tint in the face. Most free from pain when lying quict in hed, and foumd the changes of position neceled for a physical rexamination very severe. P'ain most severe over the right chest, a litile below and rather internal to the nipple. In this area could be heard a peculiar amplorie sound to be detereted nowhere else in the elest. ()ver the right apex and thenee down about two inches below the davicle a modified respiratory murmur could be hourd, and in the corresponding area in the axilla ancl back also. Over the entire lower part of the right chest, front, side and back no respiratory sounds coulil be heard; no fremitus nor tubal breathing. Pereussion gave a tympanitic liote over the ares. The physical signs were so marked that, though I had never sech a case of puen-

1 Road at the meoting of tho Bustom Socioty for Medical Improwe uvere the aflected alreic.

The next day he was somewhat ansier as to pain. and pulse and temperatire were loth a little lower. ()n getting him into an erect position, however, it was crident that some chusion was acemulating in the lower patet of the air-lilled chest arvily. Ile wats less markedly eyanotir: and when quied in bed loe Was so eatsy that, it was hatrl to get him and his wife: to realize the gravity of his eondition and my urgent rec]uest for counsel was only reluctantly acceded to. As he was feceling even (asieer the mext daly when l)r. Vickery was kind romough to all and see him in romsultation, the welenese we got was not effusive. Not wishing to bias Dr. Vickerey mind I told him nothing of what I had foumd ; in fact, unintentionally misled him by telling him the left side was at fault. 'The doctor, however, very soon si\%ed the (asce ul, as his notes will show, and, in fact, it was hard at this stage not to be struck by the pronomoced pathological comclitions present, - the effusion having increased in amount and, owing to the latere air chamber above it, shifted its level with every ehange made in the patient's position. (We speak of the liguid as an effusion leere, as at this time meithere of us believerel it wis othere thim the usual pleuritic: fuid.) Some tiresome congh having come with the development of pressure from the fluid a seclative mixture was advised, as also the continued use of the rubefiacients. $\Lambda$ s the pain was less shatp since the fluid came and the dyspmea no Worse, the palient was allowed to sit 11 and, as it was warm, to go out in a limited way. Ile was begimning to (at and his pulse and temprerature did not go 11 , nor were there any rigors. At Dr. Vickery's suggestion, aspiration was delayed in the hope of alsorption. Ilowever, at the cond of twenty-two days, as his genteral condition did not improve and there was no evidemee of the fluil recenling, it was thonght hest to aspirate. The laregest meedlo of the aspirator, after being boiled, was intorolueed in the posterior axillary line between the seventh and eighth rib, and held, after pencerating the ehest wall, approximately parallel with the diaphragmatice floor. $\Lambda \mathrm{s}$ soon as the vacum was comnected I was dismayed to see a stream of dark red blooel pour into the bottle, where only serum or, at most, pus was expeeted. Visions of amomalous veuous chiomels flashed through my miud, and I heartily wisheel I hal continued to temporize, but I felt I was in for it, and hanl better make the best of it, as I could not be lield responsible for anomalies. 'The- large needle caused great pain, and after abont thirty-four ounces had been withdrawn and the flow was becoming intermittent, the needle was withdrawn and the puncture soaled I1) asceptically with sterile cotton and collodion. No air was withdrawn and after the inmediate pain of the operation was over the patient folt casier, and in a day or two was out and about again. 'The line of flatuess was reduced by this aspiration about two and one-laalf inchess. At the end of fifteen day's the eflusion had reaceumulated and the line of flatness was as high as ever. 'The resonant air layer seemed practically unchanged - possibly a little less.

$\Lambda$ second aspiration was done witls the large necdle in the seventh interspuce, but a little further posteri- 